\title{
UTILIZATION OF STUDENT PRESENCE INNOVATION USING BARCODE TO INCREASE DISCIPLINE IN SMP N 2 DLINGO
}

\author{
Febri Safitri ${ }^{\text {a) }}$, Enung Hasanah ${ }^{\text {b) }}$ \\ ${ }^{a * b}$, Magister Manajemen Pendidikan Universitas Ahmad Dahlan \\ Yogyakarta, Indonesia. ${ }^{\left.a^{*}\right)}$ febri1400009003@webmail.uad.ac.id, b)enung.hasanah@mp.uad.ac.id
}

\begin{abstract}
Discipline is the key to educational success. One indicator that shows the level of student discipline in the education process is the level of student participation in school. The presence of students in schools is closely related to achievement. Therefore, schools in Indonesia, continue to strive to achieve high levels. The use of presence by using barcodes is one of the educational innovations that is expected to improve student discipline so that student achievement increases. The purpose of this study is 1) To explore how the process of using presence by using a barcode; 2) discuss 1) how the attendance process is done by using a barcode in increasing student discipline; 2) Knowing the supporting factors of applying the presence of barcode in schools. 3) Knowing the inhibiting factors of the application of barcode barcodes in schools. This type of research is a descriptive study with qualitative. The research subjects were determined based on purposive sampling technique. The research subjects consisted of administrative staff, teachers, and students. Data collection techniques through interviews, observation, and documentation. The data collected is equipped with interactive deductive data analysis techniques that are collected collecting data, reducing data, presenting data, and completing conclusions. The results showed: 1) The process of implementing presence by using a barcode to improve student discipline is done by making a barcode on students, students do a barcode scan on each student, on direct barcode scanning automatically their expected name on the computer, while students who do not enter are written manually according to their description; 2) Supporting factors for the implementation of barcode initiatives in schools is that there is support from parents and all school members, in addition to that there are also infrastructure facilities such as barcode machines and electricity. 3) Inhibiting factors The application of barcodes in schools is a compilation that occurs due to power outages and damage to barcode machines, as well as when barcode guards are not present at school.
\end{abstract}

Keywords: educational innovation, attendance, control, barcodes, fingerprints, barriers, student discipline

Received: 10 Jan 2020 - Revised: 11 Feb 2020 - Accepted 27 March 2020 - Available online 30 June 2020

\section{INTRODUCTION}

Discipline is an important character to be developed in students. Discipline is the basic capital for students to achieve success in the education process. Discipline is part of moral education that can be a foundation for one's development (Althof \& Berkowitz, 2006). Discipline is the strength that grows in the body that causes the workers themselves (Itang, 2015). The growth of the discipline in a person is the key to the entry of values, including the values instilled by parents and teachers (Chand, 2012). Therefore, schools and parents as educators need to consciously develop ways so that the educational process experienced by the young generation can develop the character of discipline.

The process of instilling discipline character in students requires strong support and commitment from parents and teachers. The two need to work together to build the value of students' discipline through the educational process that is held at school and home. Discipline means instructing someone to follow the "rules" of certain codes of behavior (Mehta, 2016). For example, by following positive activities in the school and outside of school. In the school, for example, following intra-school student organizations. While positive activities outside of school such as 
taking part in competitions that represent schools at the district, provincial and even country level.

Schools as educational institutions that have gained the confidence of parents to develop student discipline, need to innovate to increase the level of student attendance at school. Innovation is an idea or ideas that can be proposed to improve the existing system so that there are changes to become better or can be said to be an update. Technological innovation is widely recognized as a major competitive advantage for manufacturing and service companies, and consequently is an important driver of their economic performance (Galia, 2015). The purpose of an innovation is to be able to solve a problem that occurred in previous schools as well as an increase towards a better direction (there is a difference from the previous phase) which is done by planning, namely by applying an innovation using technological tools. Part of a school institution must have a characteristic, namely the technology owned, either from government assistance or obtained from the school itself (OCDE, n.d.). Hopefully, the applied innovation can be felt like a new product that is attractive to students or the addition of services so that they feel happy when doing so (Löfgren \& Witell, 2005).

One form of educational innovation that can be applied by schools in increasing the level of student discipline is to apply student presence by using a barcode system. Barcode is a renewal of innovation presence by prioritizing the effects of the initial labor-saving process that innovation has. Two important aspects need to be seen about the relationship between technological change and work: the possibility of an innovation-friendly impact of the product, as opposed to the innovation process; by using technology (Vivarelli, 2014). This presence using the barcode system has started to be widely used in schools in Indonesia, including in the Dlingo 2 public junior high school.

SMP Negeri 2 Dlingo is a public school located in the Mangunan area, Dlingo, Bantul,
Yogyakarta. Barcode presence systems have been implemented at SMP Negeri 2 Dlingo since the new school year in July 2019. According to preliminary observations show that in the implementation of barcode-based attendance systems, the school experienced various obstacles and challenges. Besides, there are also positive things that can provide support for the implementation of a barcodebased presence system to achieve the goal of increasing student discipline. This article seeks to explore 1) how the process of using presence by using barcodes in increasing student discipline; 2) Knowing the supporting factors of the application of innovation in the use of barcode presence in schools. 3) Determine the inhibiting factors of the application of innovation in the use of barcode presence in schools.

\section{METHODS}

SMP Negeri 2 Dlingo is a public school located in the Mangunan area, Dlingo, Bantul, Yogyakarta. Barcode presence systems have been implemented at SMP Negeri 2 Dlingo since the new school year in July 2019. According to the preliminary observations show that in the implementation of barcodebased attendance systems, the school experienced various obstacles and challenges. In addition, there are also positive things that can provide support for the implementation of a barcode-based presence system to achieve the goals of increasing student discipline. This article seeks to explore 1) how the process of using presence by using barcodes in increasing student discipline; 2) Knowing the supporting factors of the application of innovation in the use of barcode presence in schools. 3) Determine the inhibiting factors of the application of innovation in the use of barcode presence in schools.

The purpose of this study is to gain a deep understanding of a specific matter [Domholdt, 1993]. Besides, this research aims to describe and interpret issues or phenomena or events systematically from the perspective of the individual or population being studied and to produce new concepts (Viswambharan \& Priya, 2016; Mohajan \& Mohajan, 2018). 
The study was conducted at SMP Negeri 2 Dlingo. The time used by researchers in obtaining research data on School Community Participation in School-Based Management in SMP Negeri 2 Dlingo 28 to 30 October 2019. Research subjects are sources for obtaining research information (Personal \& Archive, 2018). The source of information from this study is educational staff who served as technicians in the school and students. Determination of the subject or source of data in this study was selected by purposive sampling, namely data collection techniques with certain considerations. The consideration in determining the source of information is the people involved in the planning, implementation and evaluation process of the barcode system. The object of the research object to obtain data by the objectives of this study is innovation that is implemented in schools using barcode presence.

Data is collected by open interview (Cibangu, 2012), also through observation (Zohrabi, 2013). Data collection techniques in this study were carried out periodically through: observations made at SMP Negeri 2 Dlingo, to obtain valid data from schools. After making observations at the school and the activities carried out namely student presence using barcodes Researchers conducted interviews with teachers or employees to get information related to what they want to explore from SMP Negeri 2 Dlingo. Data collection techniques using written documents from TU staff and the section responsible for student attendance using barcodes. If it can be described as follows:

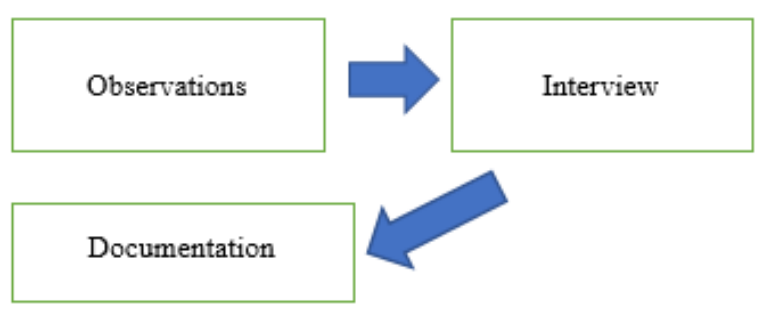

Figure 1. Data collection techniques

Data collection instrument is a matter that is used in measuring an observed natural or social event, data collection in this study uses the following steps:

a. Observation, Observation was carried out by looking at the situation and conditions in SMP Negeri 2 Dlingo. Starting from the characteristics of students, and others.

b. interview, conducted by conducting interviews with technicians who are responsible for running the barcode, along with students in the school because they feel the advantages of using barcode presence directly. c. Documentation, something obtained from SMP Negeri 2 Dlingo is student attendance data using barcodes.

The purpose of using the instrument is so that scientific writing is not out of the existing provisions, and does not go out of the context to be discussed. Before the interview takes place, the respondent must be informed of the details of the study to be investigated and be given a guarantee of ethical principles, and concern about what will be researched and write only the information needed (Gill, Stewart, Treasure, \& Chadwick, 2008).

Analysis of the data used in this research is descriptive qualitative research. Qualitative descriptive analysis is an analysis method that aims to find out data relating to student review using barcodes in SMP Negeri 2 Dlingo and can then answer and analyze problems. The analysis of data carried out by the Reduction of data means choosing the main things. Looking for themes and patterns and eliminating unnecessary data, data presentation is the process of displaying data that has been collected after going through the reduction stages. The presentation of this data is described in the form of text, and presenting data in this study is with narrative or narrated text. So that research can be easily understood, the researchers conclude the research conducted. 


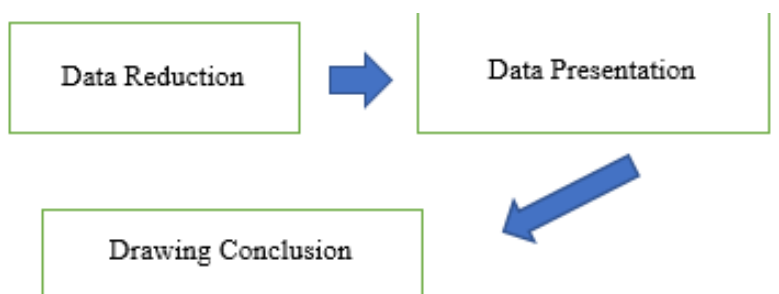

Figure 2. Data analysis process

\section{RESULTS AND DISCUSSION}

\section{A. Result}

The implementation of the implementation in SMP Negeri 2 Dlingo is a very good innovation. Implementation is intended as an update in a system. The System Prevention Support Function is conceptualized as supporting the work of those who will practice innovation (Wandersman et al., 2008). In this case, the teacher is said to be a person who has a very large role and can also become a technician in a field of study. The thing to note is the situation that is happening at school, the burden of class hours being pursued by teachers at SMP Negeri 2 Dlingo. Because indeed in Dlingo State Junior High School 2 is very short of human resources, so for the technician, it is intended for one person who is also a Guidance and Counseling teacher in the School. The human resources of an organization can be a source of competitive advantage (Journal \& Sciences, 2016). So that in his work focus on learning in children, but there is a problem that is happening in the School so that it is said to be less than optimal in the implementation of innovation. Innovation in schools is brought in to create a new system or product, in this case, it mean that HR must be prepared if there are new problems.

Innovation is said to succeed if a planned innovation is already running. In SMP Negeri 2 Dlingo innovation can be said to be successful, because it has been running

from July 2019. Activities in schools are effective if:

a. Human resources in quality schools, in this case, human resources that can be said to be qualified are those who have other skills besides carrying out their obligations properly, namely teaching. b. The school is an organization that can be used as a place for student stimulation and a place for implementing a planned innovation.

Diagram 1. Student individual data

\section{DATA INDIVIDU \\ - Yuliana Renita Sari}

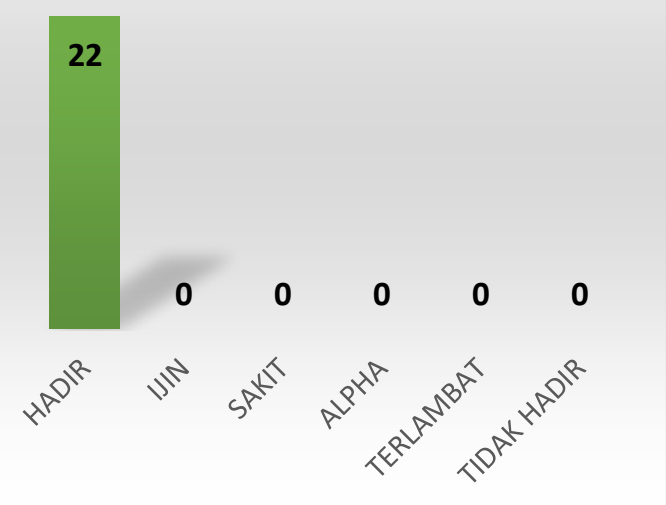

Source: Data from SMP Negeri 2 Dlingo Diagram 2. Class Data

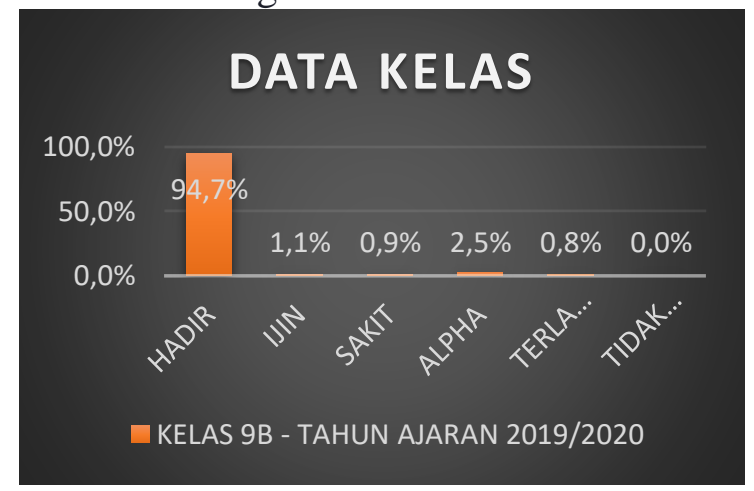

Source: Data from SMP Negeri 2 Dlingo

Based on the results of interviews, observations, and documentation, the results of this study show the following:

1) The process of using attendance by using a barcode to improve student discipline. This system uses student cards to motivate students to see attendance at school, this is in line with what was conveyed by (Saheed et al., 2016). The application of presence using a barcode scan at SMP Negeri 2 Dlingo is carried out through the following methods:

a. Using a barcode written on a student card

b. Students scan barcodes printed on student cards owned by each student

c. After a successful barcode scan, the student's name usually appears on the computer connected to the barcode scanning machined. 
While students who did not enter for some reason, the student data was entered manually by a technician, for example, students on behalf of Bayu were sick on the existing data written that students on behalf of Bayu were sick.

2) Supporting factors for the application of innovation in the presence of barcode in the School, are:

a. The socialization of the Bantul Regency government was held in the building, and there were representatives from each school participating in the socialization. The socialization was carried out to practice barcode making, the barcode can be used as well as possible. For example for library cards. But the technicians at Dlingo 2 Public Middle School have innovations in making barcodes to be included on student cards, the barcodes can be used as student presence. The hope is to facilitate the existing attendance systematics at SMP Negeri 2 Dlingo.

b. The equipment provided by the government of Bantul Regency is a Barcode machine that can be used as a Barcode scan on student cards owned by students.

c. Providing computers in schools so that they can support activities or innovations that will be implemented.

This is in line with the opinion of Saheed et al., (2016) that the majority of members in educational institutions may believe that attendance is important in achieving student success, but most of a member in an educational institution can only provide anecdotal evidence to support one's beliefs, so we need authentic evidence in the form of attendance data.

3) Factors that inhibit the adoption of innovations in the use of barcode presence in schools:

a. The socialization activities carried out were only carried out by representatives at each school. So in SMP Negeri 2 Dlingo when there were problems with machines and computers, only technicians who participated in the socialization could overcome the problems that were happening. So when technicians do not enter due to illness, the barcode machine cannot be applied properly, then no one can operate the barcode machine and the computer. b. When the power outages the barcode machine cannot be used and student attendance activities are again carried out manually. Because when the power goes out, the machine cannot be anticipated using battery aids. If the fingerprint machine used by the teacher for attendance can be connected to the battery, but if the barcode machine used by the student cannot be connected to the battery.

\section{CONCLUSION/RECOMENDATION}

Based on the results of the study, it is known that the implementation of the barcode system to improve student discipline in SMP Negeri 2 Dlingo. Student attendance activities using barcodes were carried out by the plans they had prepared because they were supported by the majority of the school community. The barcode system has also been proven to provide convenience to schools in exercising control over student discipline because it can be felt to be able to collect student attendance data. It shows that innovation in education is important in improving school performance, this means that by the results of research conducted by (OCDE, n.d. that innovation in education is an important thing in improving school performance.

The implementation of the implementation in SMP Negeri 2 Dlingo is a very good innovation. Implementation is intended as an update in a system. In SMP Negeri 2 Dlingo innovation can be said to be successful, because it has been running from July 2019. Activities in schools are effective if:

a. Human resources in high-quality schools

b. School organizations can be used as a place for student stimulation.

Based on the results of interviews, observations, and documentation, the results of this study show the following:

1. The process of using attendance by using a barcode to improve student discipline, by:
a. Using a barcode written on a student card
b. Students scan barcodes printed on student cards owned by each student
c. After successfully scanning the barcode the student's name appears on the 
computer connected to the barcode scanning machined. Whereas students who are absent for some reason, student data is entered manually.

2. Supporting factors for the application of innovation in the use of barcode presence in schools are:

a. The socialization was held by the Bantul Regency government

b. Equipment was provided by the Bantul Regency government

c. Provided a computer in the School to find out student attendance data.

3. The inhibiting factors for the adoption of innovative barcode presence in schools:

a. The socialization activities carried out were only carried out by representatives at each school.

b. When the power outages the barcode machine cannot be used and student attendance activities are carried out again

c. manually.

\section{REFERENCES}

Althof, Wolfgang \& Berkowitz, Marvin. (2006). Moral Education and Character Education: Their Relationship and Roles in Citizenship

Atmowardoyo, H. (2018). Research Methods in TEFL Studies: Descriptive Research, Case Study, Error Analysis, and R \& D. Journal of Language Teaching and Research, 9(1), 197. https://doi.org/10.17507/jltr.0901.25

Galia, F. (2015). Obstacles To Innovation and Firms Innovation Profiles: Are Challenges Different for Policy Makers? (January), 90-96. https://doi.org/10.4995/icbm.2015.1287

Gill, P., Stewart, K., Treasure, E., \& Chadwick, B. (2008). Methods of data collection in qualitative research: Interviews and focus groups. British Dental Journal, 204(6), 291295. https://doi.org/10.1038/bdj.2008.192

Itang, I. (2015). Work Discipline and Work Competence with Quality of Service in the Office of
Religious Affairs (KUA) District of Mount Kencana Lebak Regency of Banten. Journal of Management and Sustainability, 5(3), 132-140. https://doi.org/10.5539/jms.v5n3p132

Löfgren, M., \& Witell, L. (2005). Kano's Theory of Attractive Quality and Packaging. Quality Management Journal, 12(3), 7-20. https://doi.org/10.1080/10686967.2005.119192 57

Mehta, R. (2016). Effect of Discipline and Self Disciple in Students Life. International Research Journal of Management Sociology \& Humanity, 7(3), 28-35.

Mohajan, H., \& Mohajan, H. K. (2018). M P RA Munich Personal RePEc Archive Qualitative Research Methodology in Social Sciences and Related Subjects Qualitative Research Methodology in Social Sciences and Related Subjects. UTC Journal of Economic Development, Environment and People, 85654(85654), 1. Retrieved from https://mpra.ub.unimuenchen.de/85654/1/MPRA_paper_85654.pd $\mathrm{f}$

Nelson, F. M. (2002). A qualitative study of effective school discipline practices: Perceptions of administrators, tenured teachers, and parents in twenty schools. ProQuest Dissertations and Theses, $96 . \quad$ Retrieved from https://search.proquest.com/docview/30480288 2?accountid=10673http://openurl.ac.uk/redirec t/athens:edu/?url_ver=Z39.88-

2004\&rft_val_fmt=info:ofi/fmt:kev:mtx:disser tation $\&$ genre $=$ dissertations $+\&+$ theses $\&$ sid $=P r$ oQ:ProQuest+Dissertations+\&+Theses+Globa 1\&at

OCDE, O. para la C. y el D. E. (n.d.). Innovating E ducation and $\mathrm{E}$ ducating for I nnovation.

Personal, M., \& Archive, R. (2018). Munich Personal RePEc Archive Qualitative Research Methodology in Social Sciences and Related Subjects Qualitative Research Methodology in Social Sciences and Related Subjects. (85654).

Pieterse, J. H., Caniëls, M. C. J., \& Homan, T. (2012). Emerald Article: Professional discourses and resistance to change Professional discourses and resistance to change. https://doi.org/10.1108/09534811211280573

Vivarelli, M. (2014). Innovation, employment and skills in advanced and developing countries: A survey of economic literature. Journal of Economic Issues, $\quad 48(1)$, 123-154. https://doi.org/10.2753/JEI0021-3624480106 